\title{
Seizure and coma secondary to Conn's syndrome: a case report
}

\author{
Eiman Alseddeeqi ${ }^{1 *}$, Ajda Altinoz ${ }^{2}$ and Najla Ben Ghashir ${ }^{3}$
}

\begin{abstract}
Background: Conn's syndrome is a curable condition if identified properly. It is characterized by autonomous secretion of aldosterone from the adrenal gland cortex. Its morbidity is related to the increased risk of cardiovascular diseases.

Case presentation: We report the case of a 48-year-old man of African descent presenting with generalized tonicclonic seizure and coma secondary to hypertensive encephalopathy. A biochemical evaluation revealed a very high aldosterone level and an undetectable renin level, both are compatible with primary aldosteronism. The presentation of the following confirms the diagnosis of primary aldosteronism: spontaneous hypokalemia, an undetectable renin level, and a high aldosterone level. Abdominal computed tomography revealed a left adrenal adenoma. Adrenal venous sampling confirmed lateralization of aldosterone excretion from the left adrenal gland. Our patient underwent left laparoscopic adrenalectomy that confirmed a left functional adrenal adenoma. After 12 months of follow up, his hypertension was controlled on only one antihypertensive drug which was down from four drugs preoperatively.

Conclusion: Conn's syndrome, in this case, was complicated by coma secondary to seizure. Adrenalectomy normalized the hypokalemia and improved resistant hypertension. Potassium supplementation and several antihypertensives were discontinued as our patient became normokalemic and normotensive on one antihypertensive agent.
\end{abstract}

Keywords: Primary hyperaldosteronism, Unilateral adrenal adenoma, Laparoscopic adrenalectomy, Hypertensive encephalopathy, Conn's syndrome, Case report

\section{Background}

Primary aldosteronism (PA) was first described by J. W. Conn in 1955. It was described in the setting of a $4-\mathrm{cm}$ aldosterone-excreting adenoma in association with hypertension, hypokalemia, and excessive urinary excretion of aldosterone [1, 2]. Patients with increased aldosterone secretion have an increased risk of cardiovascular disease attributed to putative causes other than pure hypertension [3]. Conn's syndrome is considered one of the secondary causes of hypertension in up to $4.8 \%$ of

\footnotetext{
* Correspondence: ealseddeeqi@seha.ae

'Division of Endocrinology, Sheikh Khalifa Medical City, P.O. Box 51900, Abu Dhabi, United Arab Emirates

Full list of author information is available at the end of the article
}

cases $[4,5]$. In the early stages of the disease, serum potassium might still be within the normal range [6-9]. Normokalemic hypertension is the most frequent phenotype of PA [10].

A hypertensive emergency can present with cerebrovascular manifestations and sequela. The association between neurological manifestations, on the other hand, with PA has been described in the literature [7].

Our case is unusual since it represented the presentation of seizure in the setting of PA which one has to think of as a differential. This case report is of importance to the medical literature as it discusses a severe life-threatening presentation which is curable if addressed properly. Our case manifested with a devastating 
presentation of neurological complication presenting with seizure and coma. Unilateral adrenalectomy improves resistant hypertension and resolves hypokalemia in patients with Conn's syndrome [11-16].

\section{Case presentation}

A 48-year-old man of African descent was brought to our emergency department, unresponsive, following an episode of a generalized tonic-clonic seizure. On initial physical examination, he was comatose. Blood pressure revealed a reading of $178 / 121 \mathrm{mmHg}$, a heart rate of 105 beats/minute, and a respiratory rate of 18 breaths $/ \mathrm{mi}$ nute. His Glasgow Coma Scale was recorded as 3 out of 15 , which required intubation and admission to the intensive care unit.

Further history revealed no recreational drugs exposure, no tobacco smoking, and no alcohol consumption; he had no previous history of epilepsy or head trauma. He was not known to have any cardiac comorbidities such as ischemic heart disease or congestive heart failure. His past medical history is remarkable for resistant hypertension; he was on four anti-hypertensive agents but was non-compliant in taking them: atenolol $50 \mathrm{mg}$, spironolactone $100 \mathrm{mg}$, amlodipine $10 \mathrm{mg}$, and valsartan $160 \mathrm{mg}$. He was first diagnosed as having hypertension 20 years ago. He takes sulfonylurea for type II diabetes mellitus. His family history is remarkable for hypertension in both parents. His family history is negative for the presence of renal diseases, adrenal tumors, or any syndromes associated with adrenal tumors.

He had a body mass index (BMI) of 31. A thyroid examination was consistent with a normal size gland with no nodules and a visual field examination by confrontation to exclude multiple endocrine neoplasia (MEN) syndromes was normal. He did not appear to have cushingoid or acromegaly features.

Initial investigations showed a potassium level of 2.6 $\mathrm{mmol} / \mathrm{L}$ (normal, 3.6-5.1 mmol/L), a creatinine level of 113 micromole/L, and a blood gas analysis consistent with metabolic alkalosis. His urea level was $5.70 \mathrm{mml} / \mathrm{L}$ (normal, $2.8-8.1 \mathrm{mmol} / \mathrm{L}$ ) and creatinine kinase level read $2.2 \mathrm{mcg} / \mathrm{L}$ (normal, $<4.9 \mathrm{mcg} / \mathrm{L}$ ). Urine analysis was negative for leukocyte esterase and nitrites. A chest Xray showed no findings of congestive heart failure. A 12lead electrocardiogram (ECG) showed a sinus rhythm. Troponin- $\mathrm{T}$ level was $0.014 \mathrm{mcg} / \mathrm{L}$ (normal, $<0.014$ $\mathrm{mcg} / \mathrm{L}$ ) and brain natriuretic peptides (BNP) level was $25.9 \mathrm{ng} / \mathrm{L}$ (normal, 0-121 ng/L). Calcium level revealed a result of $2.46 \mathrm{mmol} / \mathrm{L}$ (normal, $2.23-2.58 \mathrm{mmol} / \mathrm{L}$ ). A computer tomography (CT) scan showed no brain lesions that could explain the decreased level of consciousness. A magnetic resonance imaging (MRI) of his brain was performed next day and showed no features suggestive of a mass-occupying lesion (Fig. 1).

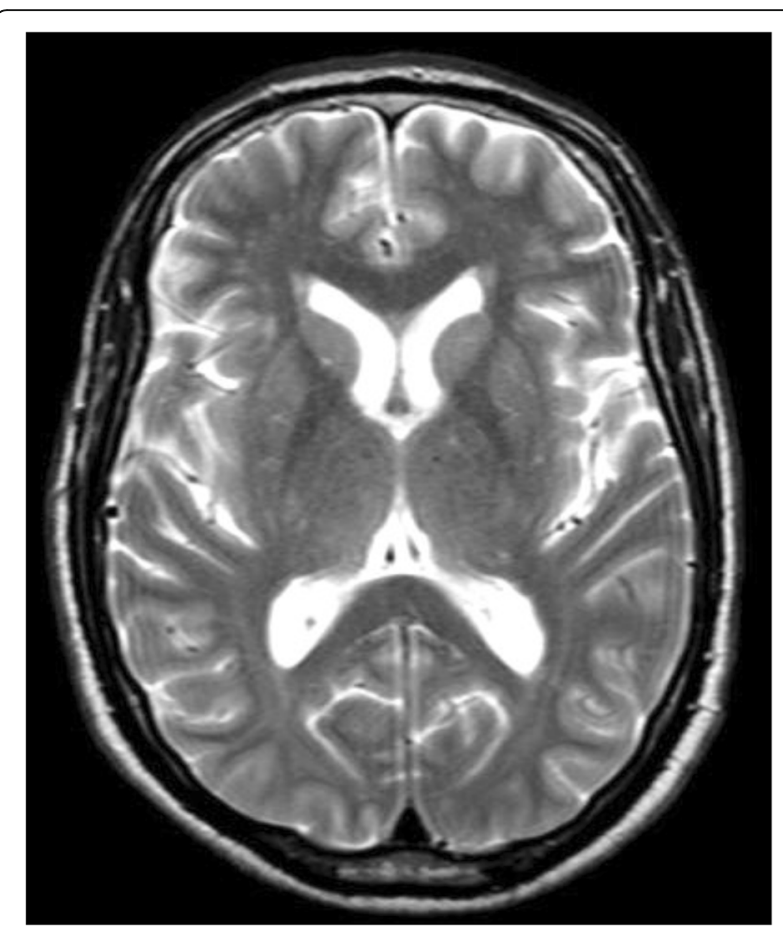

Fig. 1 Magnetic resonance imaging of the brain: T2 image, showing no lesions

An electroencephalogram was performed and it read normal. Further investigations (Table 1) revealed a potassium level of $2.6 \mathrm{mmol} / \mathrm{L}$ (normal, $3.6-5.1 \mathrm{mmol} /$ $\mathrm{L}$ ) and an aldosterone level of $36.2 \mathrm{ng} / \mathrm{dL}$ (normal, $2.8-15.8 \mathrm{ng} / \mathrm{dL}$ ) with a renin level of less than 0.081 $\mathrm{ng} / \mathrm{dL}$ (normal, $0.4-2.3 \mathrm{ng} / \mathrm{dL}$ ). Results of a 24-hour urine analysis ruled out Cushing's disease and pheochromocytoma (Table 2). Renal ultrasound and cardiac echography results excluded the presence of renovascular and cardiac causes for secondary hypertension.

Labetalol was initiated in the intensive care unit which controlled our patient's severe hypertension. He was extubated 2 days later and transferred to a regular care unit sustaining no neurological deficit. Blood pressure was controlled at $122 / 83 \mathrm{mmHg}$ on amlodipine $10 \mathrm{mg}$ daily, valsartan $160 \mathrm{mg}$ daily, spironolactone $100 \mathrm{mg}$ daily, and metoprolol $100 \mathrm{mg}$ twice daily. Potassium and magnesium required replacement to maintain levels within the normal range.

Table 1 Metabolic panel

\begin{tabular}{lll}
\hline & Result & Normal Range \\
\hline Potassium & $3.2 \mathrm{mmol} / \mathrm{L}$ & $3.6-5.1 \mathrm{mmol} / \mathrm{L}$ \\
Creatinine & $113 \mathrm{micromole} / \mathrm{L}$ & $62-106 \mathrm{micromole} / \mathrm{L}$ \\
Aldosterone & $36.2 \mathrm{ng} / \mathrm{dL}$ & $2.8-15.8 \mathrm{ng} / \mathrm{dL}$ \\
Renin & $<0.081 \mathrm{ng} / \mathrm{dL}$ & $0.4-2.3 \mathrm{ng} / \mathrm{dL}$ \\
\hline
\end{tabular}


Table 2 Investigations for pheochromocytoma and Cushing syndrome

\begin{tabular}{lll}
\hline & Results & Normal range \\
\hline Urine dopamine & $442 \mathrm{nmol} / \mathrm{L}$ & \\
Urine 24 hours dopamine & $1326 \mathrm{nmol} / \mathrm{L}$ & $<3240 \mathrm{nmol} / \mathrm{L}$ \\
Urine epinephrine & $40 \mathrm{nmol} / \mathrm{L}$ & \\
Urine 24 hours epinephrine & $120 \mathrm{nmol} / \mathrm{L}$ & $<150 \mathrm{nmol} / \mathrm{L}$ \\
Urine norepinephrine & $104 \mathrm{nmol} / \mathrm{L}$ & \\
Urine 24 hours norepinephrine & $312 \mathrm{nmol} / \mathrm{L}$ & $<570 \mathrm{nmol} / \mathrm{L}$ \\
Urine cortisol & $68 \mathrm{nmol} / \mathrm{L}$ & \\
Urine 24 hours cortisol & $204 \mathrm{nmol} / \mathrm{L}$ & $100-379 \mathrm{nmol} / \mathrm{L}$ \\
Urine metanephrine & $105 \mathrm{nmol} / \mathrm{L}$ & \\
Urine 24 hours metanephrine & $313 \mathrm{nmol} / \mathrm{L}$ & $<2000 \mathrm{nmol} / \mathrm{L}$ \\
Urine creatinine & $4.68 \mathrm{mmol} / \mathrm{L}$ & $3.45-2290 \mathrm{mmol} / \mathrm{L}$ \\
Urine 24 hours creatinine & $14.04 \mathrm{mmol} / \mathrm{L}$ & $9-21 \mathrm{mmol} / \mathrm{L}$ \\
\hline
\end{tabular}

An abdominal CT (Fig. 2) revealed a well-defined left adrenal gland lesion with an absolute washout time of $85 \%$ and a relative washout time of $50 \%$. The lesion measured $12 \times 16 \times 15 \mathrm{~mm}$ in its largest dimensions.

He stayed in our hospital until time of surgery because he lived far away from the hospital and because he was at high risk for uncontrolled severe hypertension. He needed to come off spironolactone for 4 weeks before we performed case detection tests. His potassium level was normalized afterward at $3.9 \mathrm{mmol} / \mathrm{L}$ (normal, 3.6$5.1 \mathrm{mmol} / \mathrm{L}$ ), before performing another set of tests. His aldosterone level remained at $35.3 \mathrm{ng} / \mathrm{dl}$ (normal, 2.8$15.8 \mathrm{ng} / \mathrm{dL}$ ) and renin measured less than $0.08 \mathrm{ng} / \mathrm{dl}$ (normal, $0.4-2.3 \mathrm{ng} / \mathrm{dL}$ ). Aldosterone to renin ratio

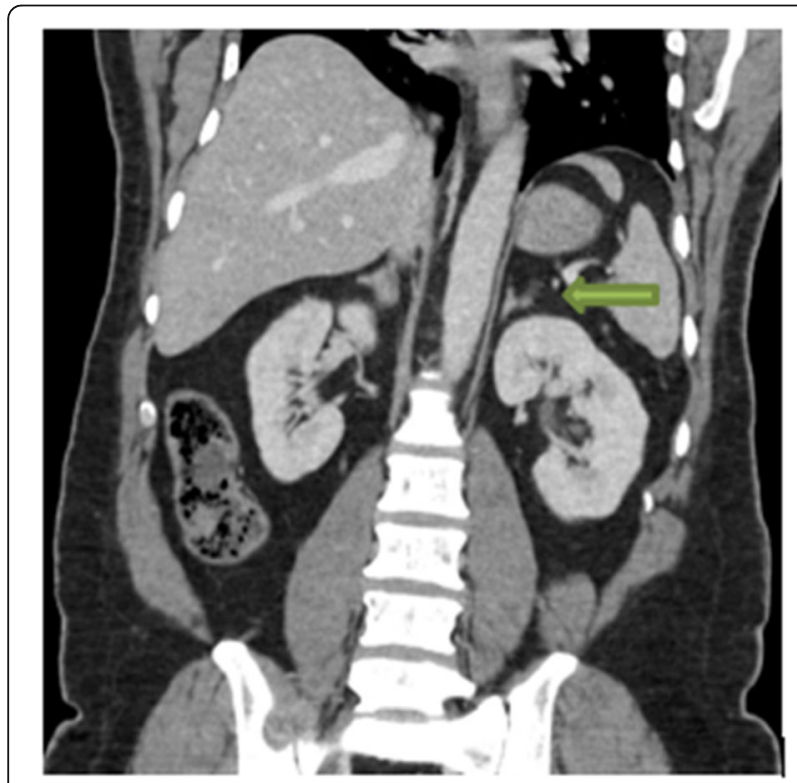

Fig. 2 Computed tomography scan of the abdomen showing left adrenal adenoma by the green arrow
(ARR) result was consistent with a level above $40 \mathrm{ng} / \mathrm{dL}$ per $\mathrm{ng} / \mathrm{mL}$ per hour (or $3.1 \mathrm{pmol} / \mathrm{L}$ per minute). A saline load confirmatory test was not performed as he presented with the following: spontaneous hypokalemia, plasma renin level measuring below detection levels, and a plasma aldosterone level above $20 \mathrm{ng} / \mathrm{dL}$.

Selective simultaneous non-stimulated adrenal venous sampling was performed and it lateralized the lesion to the left adrenal (Table 3). Adrenal vein (AV) to inferior vena cava (IVC) cortisol ratio on both sides was 19 and 15 for left and right AV, respectively (diagnostic cut-off $>5: 1$ ), which indicated successful catheterization. Aldosterone level in the left AV was $28,346 \mathrm{nmol} / \mathrm{L}$ compared to the right $\mathrm{AV}$, which was $3070 \mathrm{nmol} / \mathrm{L}$. Aldosterone to cortisol ratio of the left AV was significantly higher than that of the right one and it measured 8.7:1 (diagnostic cut-off is $>4: 1$ ).

His blood pressure was controlled on atenolol $50 \mathrm{mg}$, amlodipine $10 \mathrm{mg}$, and valsartan $160 \mathrm{mg}$ once a day and potassium supplementation while waiting for surgery. $\mathrm{He}$ underwent a unilateral left laparoscopic adrenalectomy.

A histopathologic examination of the adrenal gland showed an enlarged adrenal gland weighing $20 \mathrm{~g}$, with a discrete, bright golden yellow, ovoid nodule measuring $1 \times 1 \mathrm{~cm}$ across. Light microscopic examination demonstrated a demarcated adenomatous nodule with a compressed pseudo-capsule, comprising a proliferation of zona glomerulosa-like cells arranged in small nests and cords (Fig. 3).

His postoperative period was uneventful; his blood pressure reading recorded $140 / 87 \mathrm{mmHg}$ while on three anti-hypertensive agents and his potassium level was $3.9 \mathrm{mmol} / \mathrm{L}$ (normal, $3.6-5.1 \mathrm{mmol} / \mathrm{L}$ ) on no supplementations. At 3-month follow up, his blood pressure read $135 / 88 \mathrm{mmHg}$, while being on three anti-hypertensive agents (atenolol $50 \mathrm{mg}$, amlodipine $10 \mathrm{mg}$, and valsartan $160 \mathrm{mg}$ ), and his potassium level was at $3.8 \mathrm{mmol}$ (normal, $3.6-5.1 \mathrm{mmol}$ ) without being on supplements. Baseline aldosterone and renin levels were $13.2 \mathrm{ng} / \mathrm{dL}$ (normal, 2.8-15.8 $\mathrm{ng} / \mathrm{dL}$ ) and $0.9 \mathrm{ng} / \mathrm{dL}$ (normal, $0.4-2.3 \mathrm{ng} / \mathrm{dL}$ ), respectively. At 12 months follow up, his blood pressure was recorded as $123 / 86 \mathrm{mmHg}$ while being on only one anti-hypertensive agent: amlodipine $10 \mathrm{mg}$ daily. Potassium normalized at $4.1 \mathrm{mmol} / \mathrm{L}$ (normal, 3.6-5.1 mmol/L) while on no supplementation. Aldosterone and renin levels were at $11.4 \mathrm{ng} / \mathrm{dl}$ (nor$\mathrm{mal}, 2.8-15.8 \mathrm{ng} / \mathrm{dL}$ ) and $0.8 \mathrm{ng} / \mathrm{dl}$ (normal, $0.4-2.3$ $\mathrm{ng} / \mathrm{dL})$, respectively.

Summarizing his postoperative course: a 3-month visit showed a reduction in blood pressure and normalization of potassium level while on three antihypertensives. At 12-month visit, his blood pressure was controlled on only amlodipine $10 \mathrm{mg}$ once daily 
Table 3 Selective adrenal venous sampling

\begin{tabular}{llllc}
\hline Sample & Aldosterone $\mathrm{nmol} / \mathrm{dl}$ & $\begin{array}{l}\text { Cortisol } \\
\mathrm{mmol} / \mathrm{dl}\end{array}$ & Adrenal:IVC cortisol ratio & Cortisol corrected aldosterone ratio \\
\hline Lt. AV & 28,346 & 10,825 & 19.2 & 2.61 \\
Rt. AV & 3070 & 8658 & 15.3 & 0.3 \\
IVC & 644 & 564 & & \\
\hline
\end{tabular}

- To confirm successful catheterization; the adrenal vein cortisol-to-inferior vena cava cortisol ratio's cut off is greater than a ratio of 5:1. In this case, the ratio is 19 and 15 for left and right adrenal vein, respectively.

- A cut-off for the cortisol corrected aldosterone ratio from high side to low side of more than 4:1 is indicative of the lateralization. In this case, the ratio is 8.7:1 $A V$ adrenal vein, IVC inferior vena cava, Lt. left, Rt. right

with normalization of potassium level. A timeline of events is shown in Fig. 4.

Of note, there were no financial, language, or cultural challenges faced in this case.

\section{Discussion}

We report a case of PA due to unilateral adrenal adenoma that was complicated by seizure and coma secondary to hypertensive encephalopathy. To the best of our knowledge, this is the first case reporting a patient presenting with such severe neurological morbidity requiring intensive care management. The usual presentation for PA is resistant hypertension.

Several case reports demonstrate the magnitude of the complications sustained by primary hyperaldosteronism. The most severe complications reported were encephalopathy presenting with headache and resulting in cerebrovascular accidents, and cardiacrelated complications manifested by congestive heart failure. Our case, to the best of our knowledge, is the first one describing a presentation of seizure and coma as a result of severe elevation in blood pressure [17, 18]. Miyaji et al. reported that out of 427

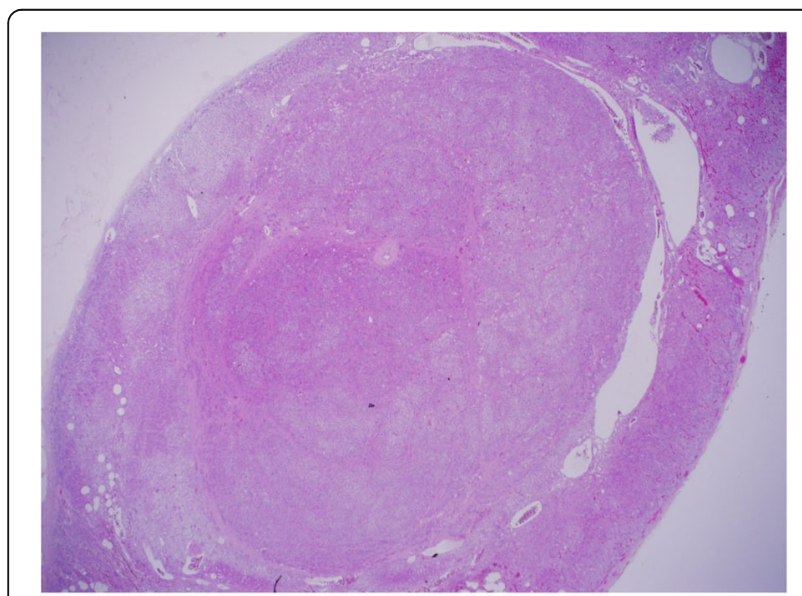

Fig. 3 A histology slide with hematoxylin and eosin stain at $\times 10$ power magnification. The adrenal gland adenoma is seen as a circumscribed nodule at the center of the field patients presenting with cerebrovascular accidents, 17 patients had confirmed PA [19]; that category was either an ischemic stroke, intracerebral hemorrhage, subarachnoid hemorrhage, or a transient ischemic attack [19] but none of them presented with seizure or coma.

The differential diagnoses for coma and seizure in our patient were excluded by detailed brain imaging. Cardiovascular risk factors leading to neurological manifestations, such as atrial fibrillation, were ruled out by a normal ECG. Renal failure and uremic encephalopathy were excluded by normal kidney function parameters. Other adrenal pathologies, such as Cushing syndrome and pheochromocytoma were excluded by a 24 -hour urine test. Therefore, the coma is explained here by severe acute rise in blood pressure.

Sub-classifying our case, Conn's syndrome was the etiology for the PA. Conn's tumor growth is slow, and resulting hypokalemia is similarly of slow progression, leading to adaptations. We, therefore, believe that the encephalopathy was related mainly to the severe sudden elevation of blood pressure rather than hypokalemia which our patient adapted to. Moreover, this adaptation explains the absence of acute clinical signs of hypokalemia and ECG changes. It is important to note that normokalemia is more common than hypokalemia in Conn's syndrome as the prevalence of hypokalemia is less than $50 \%$ [17].

Investigations for hyperaldosteronism should be performed under proper settings; that is, hypokalemia has to be corrected and medications that interfere with ARR results should be stopped for 4 weeks in advance. Verapamil, hydralazine, and doxazosin are the three common drugs that do not interfere with the plasma aldosterone concentration (PAC)/plasma renin activity (PRA) ratio. Beta-blockers and valsartan lower aldosterone level. Being on a beta-blocker or valsartan and sustaining high aldosterone level in this case strongly suggests a primary source of aldosterone secretion [20].

The following biochemical profile confirmed the diagnosis since there was spontaneous hypokalemia, undetectable renin, and a PAC above $20 \mathrm{ng} / \mathrm{dL}$ [20-24]. 

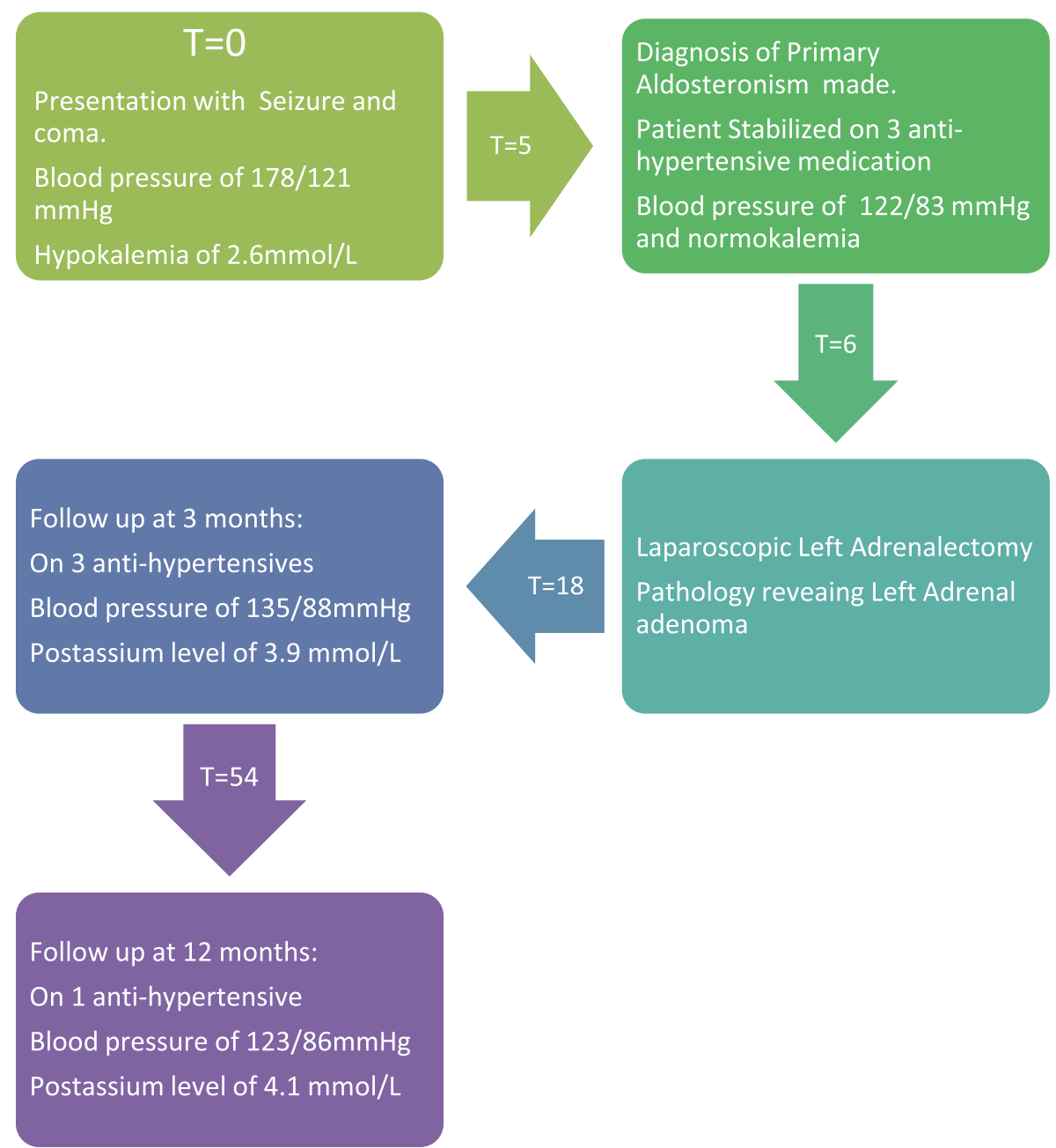

Fig. 4 Timeline of events where numerical data identifies time in weeks

Laparoscopic adrenalectomy is a treatment choice for Conn's syndrome. Although it effectively resolves the electrolyte imbalance, it might not result in a complete remission of hypertension in the majority of cases, especially in the older age group where there is an underlying component of essential hypertension [25]. An abdominal CT scan revealed an adenoma as a cause for the primary hyperaldosteronism which guided us toward surgery.

Surgery can cure hyperaldosteronism in $60-77 \%$ of cases, although it requires around a year or more for hypertension to resolve [26]. The best response to surgical treatment appears to be associated with the presence of an adenoma, an age of under 44 years, duration of hypertension of less than 5 years, and a positive preoperative response to spironolactone [27]. Surgery should prevent our patient from further severe morbidity related to hypertensive emergencies. Our patient fulfilled most of these criteria and he ended up being on one antihypertensive agent, which was needed for an underlying component of essential hypertension given the positive family history. He had partial clinical success with complete biochemical success after unilateral adrenalectomy according to Primary Aldosteronism Surgical Outcome (PASO) study criteria. The PASO criteria is a clinical score used to define response to management of PA. The score is based on six clinical parameters: blood pressure, use of antihypertensive drugs, plasma potassium and aldosterone concentrations, and plasma renin concentrations or PRAs [28].

\section{Conclusion}

We report a severe morbidity related to Conn's syndrome. Spontaneous hypokalemia and undetectable renin level along with a very high aldosterone level confirm the diagnosis of PA. The potential maximum effect of surgery can commence in up to a year. 


\section{Acknowledgements}

Not applicable.

\section{Authors' contributions}

EA and AA conceptualized the case report. AA obtained the consent form. $E A, A A$, and NBG contributed to writing the case and drafting the manuscript. NBG read the histology slide. EA, AA, and NBG critically revised the manuscript. EA, AA, and NBG approved the final submission of the manuscript.

\section{Funding}

This case report received no specific grant from any funding agency in the public, commercial, or not-for-profit sectors.

\section{Availability of data and materials}

Data sharing not applicable to this article as no datasets were generated or analyzed during the current study.

\section{Ethics approval and consent to participate} Not applicable.

\section{Consent for publication}

Consent for publication form signed by the patient is available. Written informed consent was obtained from the patient for publication of this case report and any accompanying images. A copy of the written consent is available for review by the Editor-in-Chief of this journal.

\section{Competing interests}

The authors declare that they have no competing interests.

\section{Author details}

'Division of Endocrinology, Sheikh Khalifa Medical City, P.O. Box 51900, Abu Dhabi, United Arab Emirates. 'Division of General Surgery, Tawam Hospital, Al Ain, Abu Dhabi, United Arab Emirates. ${ }^{3}$ Division of Pathology, Sheikh Khalifa Medical City, Abu Dhabi, United Arab Emirates.

Received: 19 November 2019 Accepted: 4 June 2020

Published online: 15 July 2020

\section{References}

1. Conn JW. Primary aldosteronism. J Lab Clin Med. 1955:45(4):661-4.

2. Feig BW, Ching CD. The MD Anderson Surgical Oncology Handbook. In: Duncan CB, Lee JE, editors. Adrenal Tumors. 6th edn. Philadelphia: Wolters Kluwer; 2019. p. 696-702.

3. Kayser SC, Dekkers T, Groenewound HJ, Van der Wilt GJ, Carel Bakx J, Van der Wel MC, Hernus AR, Lenders JW, Deinum J. Study Heterogeneity and Estimation of Prevalence of Primary Aldosteronism: A systemic Review and Meta-Regression Analysis. J Clin Endocrinol Metab. 2016;101(7):2826-35.

4. Rossi GP, Bernini G, Caliumi C, Desideri G, Fabris B, Ferri C, et al. PAPY study investigators. A prospective study of the prevalence of primary aldosteronism in 1,125 hypertensive patients. J Am Coll Cardiol. 2006;48(11): 2293-300.

5. Conn JW, Knopf RF, Nesbit RM. Clinical characteristics of primary aldosteronism from an analysis of 145 cases. Am J Surg. 1964;107:159-72.

6. Valloton MB. Primary hyperaldosteronism. I. Diagnosis of primary hyperaldosteronism. Clin Endocrinol. 1996;45(1):47-52.

7. Young WF. Pheochromocytoma and primary hyperaldosteronism: diagnostic approaches. Endocrinol Metab Clin N Am. 1997;26(4):801-29.

8. Ganguly A. Primary hyperaldosteronism. N Engl J Med. 1998;339(25):182834.

9. Stewart PM. Mineralocorticoid hypertension. Lancet. 1999;353(9161):1341-7.

10. Mulatero P, Monticone S, Bertello C, Viola A, Tizzani D, lannaccone A, et al. Long-term cardio- and cerebrovascular events in patients with primary aldosteronism. J Clin Endocrinol Metab. 2013;98(12):4826-33.

11. Celen O, O'Brien MJ, Melby JC, Beazley RM. Factors influencing outcome of surgery for primary aldosteronism. Arch Surg. 1996;131:646.

12. Rutherford JC, Taylor WL, Stowasser M, Gordon RD. Success of surgery for primary aldosteronism judged by residual autonomous aldosterone production. World J Surg. 1998;22(12):1243-5.

13. Sukor N, Kogovsek C, Gordon RD, Robson D, Stowasser M. Improvement in quality of life as well as in blood pressure and biochemical status following laparoscopic adrenalectomy in patients with unilateral primary aldosteronism - a pilot study. J Clin Endocrinol Metab. 2010;95(3):1360-4.

14. Lim PO, Young WF, MacDonald TM. A review of the medical treatment of primary aldosteronism. J Hypertens. 2001;19(3):353-61.

15. Stowasser M, Gordon RD, Gunasekera TG, Cowley DC, Ward G, Archibald C, et al. High rate of detection of primary aldosteronism, including surgically treatable forms, after 'non-selective' screening of hypertensive patients. J Hypertens. 2003;21(11):2149-57.

16. Lim PO, Jung RT, MacDonald TM. Raised aldosterone to renin ratio predicts antihypertensive efficacy of spironolactone: a prospective cohort follow-up study. Br J Clin Pharmacol. 1999:48(5):756-60.

17. Bortolotto LA, Cesena FH, Jatene FB, Silva HB. Malignant hypertension and hypertensive encephalopathy in primary aldosteronism caused by adrenal adenoma. Arq Bras Cardiol. 2003;81(1):97-100. 93-6.

18. Labinson PT, White WB, Tendler BE, Mansoor GA. Primary hyperaldosteronism associated with hypertensive emergencies. Am J Hypertens. 2006;19(6):623-7.

19. Miyaji Y, Kawabata Y, Joki H, Seki S, Mori K, Kamide T, Tamase A, Shima H, Nomura M, Kitamura Y, Nakaguchi H, Minami T, Tsunoda T, Sasaki M, Yamada M, Tanaka M. Primary aldosteronism in patients with acute stroke: prevalence and diagnosis during initial hospitalization. BMC Neurol. 2016;16: 177.

20. Funder JW, Carey RM, Mantero F, Murad MH, Shibata MRH, Stowasser M, Young WF Jr. The Management of Primary Aldosteronism: Case Detection, Diagnosis, and Treatment: An Endocrine Society Clinical Practice Guideline. J Clin Endocrinol Metab. 2016;101(5):1889-916.

21. Zhou Y, Zhang M, Ke S, Liu L. Hypertension outcomes of adrenalectomy in patients with primary aldosteronism: a systemic review and meta-analysis. BMC Endocr Disord. 2017;17(1):61.

22. Lee FT, Elaraj D. Evaluation and Management of Primary Hyperaldosteronism. Surg Clin North Am. 2019;99(4):731-45.

23. Byrd JB, Turcu AF, Auchus RJ. Primary Aldosteronism. Circulation. 2018; 138(8):823-35.

24. Schilbach K, Junnila RK, Bidlingmaier M. Aldosterone to renin as Screening Tool in Primary Aldosteronism. Exp Clin Endocrinol Diabetes. 2019:127(203):84-92.

25. Wierdak M, Sokołowski G, Natkaniec M, Morawiec-Sławek K, Małczak P, Major P, Hubalewska-Dydejczyk A, Budzyński A, Pędziwiatr M. Short- and long-term results of laparoscopic adrenalectomy for Conn's syndrome. Wideochir Inne Tech Maloinwazyjne. 2018;13(3):292-8.

26. Winship KM, Winstanley JHR, Hunter JM. Anaesthesia for Conn's Syndrome. Anaesthesia. 1999:54(9):564-74.

27. Shipton EA, Hugo JM. Primary aldosteronism and its importance to the anaesthesist. S Afr Med J. 1982;62:60-3.

28. Williams TA, Lenders JWM, Mulatero P, Burrello J, Rottenkolber M, Adolf C, et al. PASO study investigators. Outcomes after adrenalectomy for unilateral primary aldosteronism: an international consensus on outcome measures and analysis of remission rates in an international cohort. Lancet Diabetes Endocrinol. 2017;5(9):689-99.

\section{Publisher's Note}

Springer Nature remains neutral with regard to jurisdictional claims in published maps and institutional affiliations.

Ready to submit your research? Choose BMC and benefit from

- fast, convenient online submission

- thorough peer review by experienced researchers in your field

- rapid publication on acceptance

- support for research data, including large and complex data types

- gold Open Access which fosters wider collaboration and increased citations

- maximum visibility for your research: over $100 \mathrm{M}$ website views per year

At $\mathrm{BMC}$, research is always in progress.

Learn more biomedcentral.com/submissions 